\title{
Politics, Policy, and the UK Impact Agenda: The Promise and Pitfalls of Academic Engagement with Government
}

\author{
David Blagden \\ Strategy and Security Institute, Department of Politics \\ University of Exeter
}

\begin{abstract}
This is an open-access draft of an article accepted for publication in International Studies Perspectives:

It represents the version that the journal accepted for publication, but has not undergone copyediting or production
\end{abstract}

\begin{abstract}
The "Impact Agenda" of the UK Research Excellence Framework has major implications for the relationship of International Relations (IR) scholars, and social scientists more generally, to government policymaking - not just in Britain, but around the world. This article demonstrates that, at its worst, the Impact Agenda may struggle to capture the true contribution of scholarship to the public good, incentivize sub-optimal forms and modes of research, erode academics' property rights, see atomized academics exploited or harmed by powerful institutions, and jeopardize scholars' intellectual integrity and independence. The article also suggests, however, that these vulnerabilities can be managed by the resolution of certain key questions pertaining to scholarly conscience and expectations of reward prior to pursuing "Impact." Given that the pursuit of international peace and societal progress through teaching and research is the reason many of us choose to become professional IR scholars, the article concludes with some reflective "tips" for achieving policy influence from early in an academic career.
\end{abstract}

Keywords: Policy, Impact, Britain, Influence, Scholarship 
The past decade has seen a sustained wave of interest in the challenges and merits of achieving policy impact via scholarship on the part of International Relations (IR) scholars (Jentleson and Ratner 2011; Reus-Smit 2012; Walt 2012; Avey and Desch 2013; Byman and Kroenig 2016; Wiers 2017; Freedman 2017; Gavin 2017; Preble 2017). Yet in Britain today, few terms are as likely to induce ire and eye-rolling in any university faculty gathering as the word "Impact." The "Impact Agenda" of the UK Research Excellence Framework (REF) - the official ranking exercise of universities' research used to determine their subsequent public funding - is understood as the scourge of "pure" scholarship by some, a cash-cow to be milked by others, and a game to be played by many. This ire represents a prima facie puzzle, however. After all, professional academics represent a cohort of over-educated high-achievers who have deliberately traded off the riches and status of other potential careers to advance scientific knowledge, foster the next generation of thinkers, and see their discoveries turned to the cause of human progress in short, to have "impact." Professional scholars of politics and policy also tend, unsurprisingly, to be particularly concerned with policy and politics. So why do so many roll their eyes (or worse) at the REF Agenda? How did a profession obsessed with impact come to be so skeptical of "Impact"?

Britain's Impact Agenda merits consideration by the global community of IR scholars, as opposed to solely UK-based academics, for six reasons. First, the implicit focus of the recent wave of IR scholarship on academia-policy links has been predominantly American-centric (Gavin 2017, 270). Of course, the U.S. "Beltway-Ivory Tower" relationship is the most important connection in this domain, due to the size of the U.S. scholarly community and the global reach of U.S. policy. Yet this recognition needs caveating with two further points. Second, therefore, many non-British scholars - particularly international PhD graduates - are looking at UK academic career opportunities, given the tightness of their home job markets. The REF and its Impact Agenda require understanding as key aspects of the professional landscape for British and non-British scholars alike for the foreseeable future in UK academia: forewarned is forearmed. Third, moreover, while U.S. policy may indeed be most consequential globally, Britain remains a systemically-significant major power whose policy decisions still reverberate internationally. Choices such as the Anglo-French militarization of the "Responsibility to Protect" (R2P) concept against Libya in 2011 (Bellamy and Williams 2011), Parliament's vote against military intervention in Syria in 2013 that unwound Franco-American momentum behind 
such a move (Porter 2016), and of course, Britain's dramatic 2017 commencement of the "Brexit" process to leave the European Union (Blagden 2017) have all had substantial international ramifications. UK government policy is therefore still worth influencing. Fourth, and more generally, a study of the UK "Impact" climate sheds light on the up- and downsides of influencing policy through scholarship - with other governments or multilateral organizations, say - and obstacles to doing so. Fifth, as a specific manifestation of the previous point, the weighting of "Impact" in UK universities' REF-linked funding settlements makes for a unique case study in the incentives and distortions generated by such official mandate. And sixth, given the current wave of "anti-expert" hostility even in hitherto liberal states with a longstanding commitment to evidence-based science (Hoffman 2016; Mance 2016; Krauss 2016; Nichols 2017), dogged scholarly engagement with policy has never been more important - in Britain, America, and around the world.

This article appraises the Impact Agenda as it applies to scholarship in general and the social sciences in particular. It focuses specifically on the contribution of IR and related fields to the formation and improvement of public policy, examining both the promise that increased attention to the public impact of social research offers and several of the potential pitfalls that may have given "Impact" - at least in its REF-mandated guise - a bad name. The analysis pertains predominantly to foreign and defense policy, due to the author's specialist sub-field, but its conclusions - like some of its examples - aspire to apply more widely. It is therefore focused on influencing national-level policy outcomes, although influence on other areas of public life local government, civil society, economic productivity, multilateral organizations, and so forth are also valuable areas of scholarly engagement, and recognized as such by the REF.

The article's purpose is to raise key questions about the Impact Agenda and academics' activities under its aegis, even if it cannot satisfactorily answer them all. These questions are not all new (Martin 2011; Oliver 2014; Ní Mhurchú et al. 2016), and many were even flagged before the formal introduction of "impact" to the REF (Smith, Ward, and House 2011), but they nonetheless merit exploration in the specific context of IR scholars aspiring to policy influence. It is written from an early-career perspective, when achieving policy access - which is not itself the same as influence or impact, although it is a common precursor to both - is often most difficult. Senior faculty members with more experience of impact activities may be able to offer alternative perspectives. One of the author's "unique selling points," meanwhile, is experience of 
conducting external consultations in a UK government department. The article therefore offers perspectives from "both sides of the fence," having been both a receiver and a submitter of academic attempts to engage with policy. Along the way, it contributes to a live disciplinary debate (Flinders and John 2013) as to whether political science is already amply engaged in analysis of "real-world" importance (John 2012), or whether it needs to become more publicly and politically active to survive (Flinders 2012).

First, the article explains the "Impact Agenda" and its origins. Second, it identifies positive prospects that emerge from this growing focus on the public- and policy-relevance of social-scientific advancement. Third, it examines some of the potentially negative aspects of academic engagement with policy, both in general and under the specific auspices of the REF Agenda. Finally, it offers some reflective "tips" for achieving impact whilst navigating the possible pitfalls of "Impact," based on the author's (admittedly limited, but at least early-careerfocused) experience. The article thus develops two different - but related - themes. On the one hand, it concludes that REF-mandated "Impact" has key failings that necessitate instrumental game-playing, while academic engagement with public policy more generally is potentially perilous for atomized, institutionally weak individual scholars, particularly at junior levels. It also concludes, however, that public impact through research can and should remain among the highest aspirations of the professional academic, while the downsides of policy engagement can be mitigated by identifying and answering certain questions about one's personal intellectual integrity and expectations of reward in advance. In that spirit, its recommendations for achieving policy influence at an early career stage are offered despite - and to surmount - the Impact Agenda's various pitfalls.

\section{What is the "Impact Agenda"?}

The UK Higher Education Funding Councils introduced "Impact" as a criterion for assessing scholarly contribution in the most recent Research Excellence Framework, conducted in 2014 (REF 2012a). At first glance, this may not seem a significant development: English universities' total income amounted to $£ 29.08$ bn in 2015-16 (HEFCE 2017c, 8), for example, while the REFdetermined Quality-Related (QR) "Block Grant" accounted for only £1.56bn of that (HEFCE 2015, 5-6). ${ }^{1}$ In context, though, that figure was bigger than the sector's $£ 1.52 \mathrm{bn}$ operating surplus (HEFCE 2017c, 2). Because it is fixed between REFs and can be spent flexibly, 
moreover - as opposed to for prescribed purposes, such as teaching or capital investment - it forms the basis for most universities' ongoing support to research, particularly those outside Oxbridge that lack substantial private endowments. And it is doubly important to the support of research in the social sciences and humanities, fields that typically attract less project-specific external funding than natural/medical/engineering sciences. ${ }^{2}$ For all its limitations (Sayer 2014), therefore, doing well in the REF is a matter of supremely high stakes for British universities' ability to sustain research (Ratcliffe 2014; Brennan 2015) - and "Impact" is now a large and growing part of that, as discussed below.

Despite its REF-induced contemporary prominence, however, linking state-provided research funding to excellence in a way that defines "excellence" as including economic and societal contribution is not a new idea in Britain, and neither is lamenting the distortionary incentives that such rankings create (Macilwain 2009). REF2014's precursor - the 2008 Research Assessment Exercise (RAE) - had explicit criteria for weighing the contribution of “applied" research (RAE 2008), although it did not yet make "impact" an independent metric of research quality. ${ }^{3}$ Going back further still, the idea that publicly-funded UK universities should deliver measurable value to the economy, as well as intellectual excellence, derives from the "Three Es" drive in public spending - "Economy, Efficiency, and Effectiveness" - of Margaret Thatcher's premiership (Martin 2011, 247; Vincent 2015). The contemporary REF's first precursor was conducted in 1986 (Stern 2016,8) - though many scholars in the British academy valued the contribution of scholarship to the public good long before the government mandated that they should do so, of course (Dahrendorf 1968). REF Impact is thus not the "leading edge" of academic engagement with policy, in Britain or anywhere else, but it is nonetheless a powerful element of the UK government's university funding allocation mechanism that incentivizes certain behaviors - some of them desirable, some of them less so (Hicks 2012).

Scholarly excellence (measured by "originality," "significance," and "rigor") of research “outputs" (books and journal articles) accounted for 65 percent of departments' overall "quality profile" in REF2014, while "impact" (measured by "reach" and "significance") accounted for a further 20 percent (REF 2012a). In REF2021, this will increase to 25 percent (HEFCE 2017b, 13) following a recent review (Stern 2016), with "outputs" falling to only 60 percent, confirming the former's growing prominence. Impact is assessed by REF Panels of senior scholars, via departments" "Impact Case Studies":5 effectively portfolios demonstrating how particular pieces 
of academic research, themselves of high enough quality to be assessed as REF "outputs," have yielded positive effects for the economy and/or wider society. Performing well against such criteria is financially imperative, since "Impact" contributes substantially to REF score, and overall REF scores determine universities'subsequent QR research funding settlement (Francis 2011, 5; Rogers et. al. 2014, 2). ${ }^{6}$ It is noteworthy, however, that British REF stipulations do not go so far as the alterations proposed by U.S. Senator Tom Coburn that only political science research that enhances American national security/prosperity should receive U.S. National Science Foundation funding (Mervis 2014) - UK government has focused on incentivizing preferred behavior, rather than barring state support to certain areas of research.

Of course, "original," "significant," and "rigorous" research will make an impression within its academic field based on those qualities alone. The REF defines research as having "Impact" through "reach" and "significance" outside academic fields, however, defined as "an effect on, change or benefit to the economy, society, culture, public policy or services, health, the environment or quality of life, beyond academia" (HEFCE et. al 2015). ${ }^{7}$ As the UK Research Councils (RCUK) put it, "economic and societal impacts embrace all the extremely diverse ways in which research-related knowledge and skills benefit individuals, organizations and nations by: fostering global economic performance, and specifically the economic competitiveness of the United Kingdom; increasing the effectiveness of public services and policy; and enhancing quality of life, health and creative output" (RCUK 2012a). "Impact" can therefore take many forms and does not necessarily have to mean policy influence (Stern 2016, 23). It could instead mean a spinoff start-up company, a well-attended public exhibition, or a popular software download. There is, nonetheless, a distinctive and instrumental focus on economic and social benefit, with an assumption of research-driven prosperity and progressive change. Indeed, REF2014's Impact Agenda arose from the mandate to maximize universities' economic return following the 2010 general election as part of the effort to increase national prosperity while pursuing fiscal consolidation (Cable and Willetts 2010; Vincent 2015). The straitened public spending backdrop in the aftermath of the 2008-9 financial crisis, which affected the financecentric UK economy particularly severely (Seager, Kollewe, and Hopkins 2009), gave rise to the 2010-15 Conservative-Liberal coalition government's supreme focus on deficit reduction. The “impact” criterion centered around scholarship's direct economic benefit - above and beyond RAE2008's mere recognition of "applied" research - was thus critical to preserving any level of 
state support to university research.

Whether the Impact Agenda is needed within British IR - or has had much affect since its inception - is a matter of perspective. The Teaching, Research, and International Policy (TRIP) Project found in its faculty survey over 2008-11 that only 19 percent of UK-based IR academics self-identified as doing "primarily applied" or "more applied than basic" research - compared to 23 percent in the United States, and 69 percent answering "primarily basic" or "more basic than applied" (Maliniak, Peterson, and Tierney 2012, 37). By the survey of 2014 - after the incorporation of "impact" into the REF and its associated incentivization - the figure had barely shifted, at 20 percent (Maliniak, Peterson, Powers, and Tierney 2014, \#36). That said, between the 2011 and 2014 surveys, the number of scholars answering "both about equally" in their balance of basic-versus-applied research increased from 13 to 20 percent - so the number of scholars reporting that applied work accounts for at least an equal amount of their research rose from 32 to 40 percent in total. The number saying that they had consulted (paid/unpaid) for the UK government also came in at 21 percent (2014, \#36). The previous data (2012, 59-60) demarcated paid (10 percent) and unpaid (14 percent) consultancy, so is not directly comparable - but assuming that the paid/unpaid percentages in 2011 covered many of the same individuals, 2014's combined 21 percent may imply some modest uptick.

For those who believe the primary aim of universities should be conduct research with immediately marketable/policy-implementable implications, therefore, much seemingly remains to be done (i.e. applied research remains a distinct minority). For those who believe that the "Impact Agenda" poses a threat to universities' core mission of foundational science, by contrast, then it could be read as already having an insidious effect in IR (i.e. an 8 percent shift away from basic research over just three years). Either way, such data is hardly conclusive; it will thus be interesting to see how the proportions shift in future TRIP surveys. And it is important to note that such crude "applied" versus "basic" self-identification captures only one element of the Impact Agenda's potential influence on scholarly behavior. For Impact's proponents, it is less about driving scholars away from foundational research and more about maximizing the public benefit derived from scientific discoveries. For the Agenda's opponents, by contrast, sub-optimal dislocation of research priorities is but one of its many potential distortionary consequences. As such, TRIP surveys' "applied" versus "basic" questions are unlikely to ever precisely capture the Impact Agenda's full consequences for UK-based IR 
scholarship, be they positive or negative.

On the recommendations of the government-commissioned Stern Review, the UK funding councils will run the next REF in 2021 (Stern 2016, 32; HEFCE 2016b, 6; HEFCE 2017b). Impact was lauded by Stern as “one of the success stories of REF2014” (Stern 2016, 2122; HEFCE 2016b, 18-24; Rogers et. al. 2014, 2; Wilsdon 2016); a HEFCE-commissioned RAND study similarly concluded that "Confidence in outcomes, and in the processes used in the research impact assessment, were relatively high" (Manville et al. 2015, xvi). Accordingly, "impact" has moved from 20 to 25 percent of total REF score (HEFCE 2017b, 13) - although Stern's proposal to assess overall "Institutional Impact" has been postponed beyond 2021 (Else 2017). Further micro-level details on REF2021's conduct, including specific number and structure of Impact Case Studies in order to "deepen and broaden" the understanding of "impact" (HEFCE 2017b, 13), are still to be announced. "Pathways to Impact" must also now be incorporated into the design of proposals for Research Council funding (RCUK 2012a; RCUK 2012 b) - the other pillar of Britain's “dual support” public research funding system, alongside HEFCE's Block Grants to whole institutions - which provide competitive financial support to specific projects. The government focus on "value-for-money" deliverance of prosperity/security in exchange for public funding - including university spending - thus looks set to remain (Universities UK 2015; HM Government 2016a; Giles 2016). And with Brexit exacerbating financial uncertainty in UK Higher Education, pressure to conduct "impactful" research that enhances British competitiveness will only grow. Loved or otherwise, therefore, the "Impact Agenda" will be a feature of UK academic life for the foreseeable future.

\section{The Promise of Public Policy Engagement}

As noted, academics generally forego more lucrative careers to enhance human knowledge, pass that knowledge on to students, and see that knowledge deliver positive payoffs for humanity. Having an impact - albeit not necessarily construed in terms of policy influence, which as noted above, many IR scholars remain understandably indifferent to - is thus why most of us pursue academia (Walt 2012; Flinders and John 2013), even if not so narrowly conceived as REFdefined "Impact." At the very least, we are deeply immersed in a subject and have a vested interest in advancing our field - and probably, therefore, want the public and policymakers to appreciate its importance too. We even, arguably, have a moral duty - a social contract - to 
maximize the public benefits of the academic knowledge that we have been privileged enough to accrue (Martin 2011, 247; Francis 2011, 6; Jentleson and Ratner 2011, 6; Phipps 2014). And for its part, policy practice certainly benefits from scholars' theoretical and empirical insights (Walt 2005; Nye 2008; Reus-Smit 2012; Stoker and Evans 2016, 1); the limited influence of academic expertise on UK government is often identified as a source of recent British foreign/defense policy failings, for example (Strachan 2009; Porter 2010). In short, impact matters, and was a core part of our profession (Dahrendorf 1968; Nau 2008) before the REF formalized the requirement. Indeed, given that many academics have long been engaged in publicly valuable intellectual activity beyond teaching and published research, the Impact Agenda provides scope for that to gain recognition (Rogers et. al. 2014, 2).

For many social scientists, particularly scholars of international politics and security, academic research and knowledge can most readily have impact through influencing government policy (or, increasingly, non-governmental or inter-governmental organizations). As such, while the REF's Impact Agenda recognizes "non-traditional" forms of impact, there is enduring value in the "traditional" approach of seeking to inform and improve policymaking through academic engagement and contribution.

It is therefore fortuitous that opportunities for academic involvement in British government policy formulation are increasing, albeit modestly. Part of this owes to conscious efforts by the likes of RCUK to achieve improved access as a precursor to impact, although it is also a consequence of coincidental trends. Closure of policymaking communities to external thinkers can have its upsides: the optimistic assumptions about low-cost, high-efficacy regime change underpinning the 2003 Iraq invasion, for example, were more readily devised in the reality-detached climate of American neoconservative think-tanks and then imported into government (Arin 2014) than they may have been in a country with a less permeable, less partisan civil service. ${ }^{9}$ And it is not as if UK security policymaking has recently blossomed as some barrier-free arena of academic engagement, or is about to anytime soon (Rayner 2011; Farmer 2014; Newton 2015, 1-7); impediments of official information and classification, opaque/inaccessible policymaking communities, and political expediency overriding policy expertise persist.

Nonetheless, opportunities for academic engagement with UK policymaking, even in the traditionally-secretive foreign and defense sectors, are proliferating. The 2015 National Security 
Strategy/Strategic Defence and Security Review (NSS/SDSR) was the first such exercise in Britain to feature a public consultation suitable for academics with issue-/area-specific expertise to contribute to the overall "macro-document" that sets the framework for all UK national security policymaking (HM Government 2015b). The Chief of the Defence Staff's Strategic Forum has represented an effort to bring external experts into a quasi-institutionalized structure for providing consultation and critique (Strachan 2013, 49). Policymaking departments, including those covering foreign affairs, increasingly seek advice from - or even contract whole projects to - external experts, including academics (Ministry of Defence 2015; HM Government 2016b). ${ }^{10}$ Academic secondments into policymaking departments, while not as regular or developed as those in the United States (Blagden 2015a, 12-13; Bridging the Gap Project 2015a; Andrews et al. 2016; Himmrich 2016, 1-2), are appearing (ESRC 2016, 2017b). Attitudes towards encouraging academic debate and engagement are now favorable even in organizations with good reasons to be secretive, such as the Atomic Weapons Establishment and the Defence Science and Technology Laboratory (HM Government 2014a). ${ }^{11}$ The rise of Parliamentary Select Committee activism (Dunleavy and Muir 2013), meanwhile, provides increasingly visible and influential inquiries to which academics can contribute, which in turn can pressure government and impact public opinion via media reportage.

Alongside increasing consultation opportunities, the growth and diversification of outlets for popular writing and expert commentary similarly offers opportunities for academics to shape policy. This can impact public opinion in a way that then sways policymakers - usually only a modest effect, except for uncommonly high-profile scholars - and/or raise the academic's public profile in a way that leads policymakers to heed their advice. Digital publishing's reduced column-inch constraints mean that opportunities to write for outlets like The Guardian, The Independent, The Spectator, the New Statesman, and so forth, have grown exponentially. Some are more open than others about how contributors should submit a piece for consideration: The Guardian (2010) has a dedicated webpage (even if most pitches go unanswered), but sometimes it can be an exercise in tracking down editors via Twitter. ${ }^{12}$ Similarly, the proliferation of specialist and semi-specialist majority-online or online-only magazines and blogs - like The Conversation (for academically-informed analysis), WarOnTheRocks (U.S.-based, for foreign/defense policy), ConservativeHome and LeftFootForward (for partisan perspectives) provide further opportunities for academics in profile-raising, policy-influencing punditry. 
Writing such pieces can aid wider dissemination of "proper" academic publications, via embedded hyperlinks or other references. It can also help time-pressured journalists identify potential television/radio commentators when a relevant story breaks. Social media provides further opportunities to build profile, identify media contacts (bureaucratic officials are unlikely to be so visible), circulate writings to a wider audience, and keep track of policy/media developments to which one could contribute.

The resources available for engagement activities have also increased since 2010 despite nationwide fiscal consolidation - not least because the Impact Agenda has incentivized it. Again, this is partly coincidental: the growing activism of UK think-tanks, for example, has resulted in programs (at least in the foreign/defense policy field) explicitly pitched at enabling early-career scholars to present work to policy audiences and make connections with relevant policy/media contacts. ${ }^{13}$ But much of it owes directly to REF-motivated, RCUK-channeled money: the creation of RCUK Impact Acceleration Accounts (RCUK 2014a) in anticipation of a heavier weighting for "Impact" at REF2021 has facilitated engagement events to disseminate research findings to policymakers and other stakeholders, for example. The same goes for the resources for "Pathways to Impact" now embedded within RCUK-funded research projects. These funding streams may help to maximize the social benefits of scholarship.

Alongside potential societal benefit, "Impact" may also offer instrumental payoffs to the individual academic (Matthews 2011). First, the "public" and "scholarly" domains of academic life can be mutually reinforcing. Active policy/public engagement may prompt greater appreciation of a particular issue-area's real-world complexity and associated politics, a deeper knowledge of a particular policy domain, or improved access (to information, individuals, and so on) for future research (Freedman 2017, 264). Being highly regarded in public engagement may enhance scholarly status and regard (with caveats, discussed subsequently), and vice versa. Second, early-career pro bono policy/media work may lead to subsequent paid opportunities as a consultant or columnist (with caveats, discussed below). ${ }^{14}$ Third, being active in current policy debates can provide teaching material, while extending policy experience into teaching approaches - by assigning "ministerial submission" writing exercises or hosting simulation exercises, for example - can boost students' engagement and develop their employability (McMahon 2007). And many students, especially those attracted to fields with clear policy applicability like the social sciences, are actively drawn in by "real-world" debates and 
decisions.

Ultimately, in a world of tight budgets and complex challenges, there is a desire - up to a point, bounded by politics and vested interests - in both policymaking and media organizations to utilize academic knowledge, which is often free to them (or at least relatively cheap), for explaining and resolving problems that they themselves lack the expertise to handle optimally. The challenge for the impact-inclined academic is to work out how to realize such opportunity and how to manage the many potential pitfalls, discussed below.

\section{The Perils of Impact and "Impact"}

Despite the previous section's advocacy of scholarly impact, the "Impact Agenda" was greeted skeptically by many (Phillips 2010, 447), and has become deeply unpopular with others over time (Francis 2011,5). This cannot solely be down to academics' temperamental cynicism. More generally, the relationship between research-derived evidence and public policy has long been recognized as not universally characterized by straightforward positive progress (Weiss 1979). This section therefore lays out five of the criticisms levelled at both scholarly engagement with policy in general and the REF's conception of "Impact" in particular. They are offered as criticisms-in-principle, to avoid naming specific examples/individuals, but these are not hypotheticals: they are already live problems with concrete manifestations, as many readers will recognize from their own experience.

Of course, academics retain agency throughout: neither universities nor government departments compel faculty members to achieve impact. Even if crude rules mandating policy engagement were to be added to academics' contracts in some hypothetical future, they could likely be gamed/dodged. Individuals will retain choices over their career trajectories, professional goals, research priorities, institutional affiliations, and so forth. Nonetheless, the pursuit of policy engagement - particularly in REF-conceived form - creates powerful and potentially distortionary incentives. The five criticisms below fall within this vein.

\section{Linearity and the Limitations of Impact "Capture"}

First, much of the eye-rolling over "Impact" owes to the seemingly contrived, simplistically mechanistic, unrealistically linear way in which the REF seeks to "capture" and assess it (Oliver 2014). The Impact Case Studies by which REF2014 sought to measure impact (REF 2012b) - in 
addition to their labor-intensity, administrative burden, and associated opportunity-costs (Sayer 2014; Else 2017) - rested on tracing a causal relationship between a piece of "REF-able" published research (that is, a qualifying REF "output") and a positive economic/social outcome. ${ }^{15}$ This rendered "Impact" a game to be played (Francis 2011, 5; Oliver 2014): given the length of the journal publishing process, and the fact that work often goes through many iterations and presentations (including exposure to policymakers) before the "final" article/book appears, the impact narrative may need to be "creatively" written to give the appearance of linear cause/effect (Ní Mhurchú et al. 2016, 66-68).

Such an approach can have more pernicious effects than a mere requirement for creative form-filling and hoop-jumping, however. It may struggle to properly capture long-term relationships, whereby an academic and a policy community work together to refine each other's thought, but without any particular piece of research underpinning a change in behavior (Ní Mhurchú et al. 2016, 63-65). It may similarly miss diffuse effects - hardly a new observation (Weiss 1979, 427; Wilson 1987) - whereby an academic is one participant in a scholarly community that eventually shifts policy consensus, but in which it also proves difficult to identify the causal role of any individual academic (barring potentially the most senior/prominent). ${ }^{16}$ For example, before 2010, the conventional wisdom in "War-on-Terror-era" UK government was that counterinsurgency (COIN) and "Afghan-like" wars were the future; academics arguing for caution about the resurgence of major-power competition, and suggesting that COIN was unlikely to be hastily repeated after Iraq/Afghanistan, were marginal (Blagden 2009). Following the fiscally-constrained 2010 NSS/SDSR, the stand-off "no-boots-on-theground" Libya campaign, and Russia's recent belligerence in Eastern Europe, by contrast, reluctance to pursue COIN-based nation-building in the Islamic world and the idea that UK defense should hedge against hostile major powers have returned as commonplace (HM Government 2015a, 18-19). But this shift had many influences and could not plausibly be traced to any single academic intervention, or even a group of interveners. Major evolutions of thought or changes of practice in an area with such high stakes as national security policy are rarely "start/stop"; they emerge interactively through debate, over time, and in the face of external pressures (Weiss 1979, 428-429; Ní Mhurchú et al. 2016, 63-65). They can therefore be hard to capture in an "Impact Case Study," but that does not mean that academic contributions were not valuable. 
The same goes for academics whose research pertains to a highly stable/sclerotic policy area. Britain's nuclear posture, for example - based on four ballistic missile submarines, with one continuously on patrol so as to avoid first-strike incentives - has been effectively unchanged since the introduction of the Polaris-carrying Resolution-class submarines in 1968. That does not mean that UK academics focused on nuclear deterrence, disarmament, and security are not advancing an area of active policy contestation (BBC 2016); indeed, a Prime Minister Jeremy Corbyn could yet blow apart the previous bipartisan nuclear consensus. But the bias towards causing progressive change built into the REF definition of "Impact" may make it harder to prove impact when there is little observable variation (Lloyd 2016). ${ }^{17}$ Moreover, observable change is not necessarily a good in itself; an existing policy may be the best available option, and thus in need of protection, not alteration.

Another variant of this critique is the false dichotomy between "academic" and "realworld" impact. That the "Impact" methodology should value more than scholarly excellence alone - which tends to correlate with impact within an academic field - is understandable. But much of the best science percolated through to policymaking and public awareness anyway, even before the REF - possibly helped by the absence of distortionary incentives that the Impact Agenda can create. This raises the possibility of tension between competing understandings of "research excellence" embedded in the REF criteria, following the premise that any time spent doing one sort of academic activity is time not spent doing another. The "rigor" criterion applied to research outputs can, when construed as complex theory or sophisticated data-analysis, preclude dissemination via the channels most engaged by policymakers and the public - and conversely, striving for "impactful" research may preclude publication in the sorts of outlets most likely to be construed as "rigorous" (and thus "excellent"). Of course, well-designed research projects can often be configured to yield both high-sophistication scientific publications and general-interest/policy interpretations thereof - but such translation is not always seamless, or even possible, and all time spent on one form of writing/engagement is time not spent on another. Given that REF "stardom" is the ultimate quality on which UK faculty members' job security and prospects rest, this creates dangers - especially for early-career scholars - in the incentives that universities pass on to their academic employees. As academic institutions pressure their staff to become more "impactful," responding to one set of REF incentives, there is a risk - not unlike the relevance-versus-rigor tensions that can afflict U.S. tenure processes 
(Gavin 2017, 269) - that they will subsequently sanction those same staff for failing to meet other REF-defined measures of excellence (Freedman 2017, 264). Faculty members therefore face incentives to ensure that they are doing just enough of both to hedge against capricious variation in future institutional policy priorities, which may not be a recipe for excellence in either domain. The same goes for universities' impact-maximizing drive towards “interdisciplinarity," which - while potentially more useful to policymakers (Gavin 2017, 273) can similarly have a career-jeopardizing depressant effect on academic productivity (Leahey, Beckman, and Stanko 2017). All aspects of scholarly activity entail trade-offs; no set of incentives and subsequent behaviors is cost-free.

Illustrating the artificiality of the "academic/real-world" distinction, some of the most influential "big ideas" of post-1945 foreign/defense policy - nuclear peace through deterrence (Brodie 1946), "soft" power (Nye 1990), the social "taboo" on nuclear weapons (Tannenwald 1999), etc - have transformed public discourse by filling a gap in human understanding. The "originality," "significance," and "rigor" that the REF uses to assess scholarly excellence were also the characteristics that saw these ideas transform policy debates. Whether they represent the linear change envisaged by an Impact Case Study, however, is contestable - and if they had had to be designed as research projects that could only garner funding via a "Pathways to Impact" statement, or aligned with the five-year REF cycle, they may not have resulted in field-defining research. Similarly, Tannenwald's high-impact project on the norms constraining nuclear use built on emerging theoretical work on the role of norms in international relations (Klotz 1995; Finnemore and Sikkink 1998), which itself built on conceptual work on the role of social pressures in the international system (Bull 1977; Wendt 1992). Such theoretical work has thus been hugely impactful, in the end, but may not qualify for an "Impact Case Study" if produced in Britain today.

Indeed, the five-year cycle effectively forces the REF conception of "Impact" to operate with a steep discount rate against possible future payoffs. The underlying research may have occurred in a previous REF cycle, but at least for REF2014, the "Impact" itself had to have happened in the most recent REF cycle to "count," further diminishing the ability of the "Case Study" to capture long-term, diffuse impacts in potentially-sclerotic policy areas.

Linear impact measurement is not necessarily the "fault" of HEFCE, RCUK, or anyone else. Once tasked by government to demonstrate economic/social "value-added" from scientific 
research via the REF - not an unreasonable demand, given government's mandate to use taxpayers' money stringently against a challenging economic backdrop - some such methodology was inevitable. Moreover, because it needs to provide "mass-produced" assessment, some crudeness of criteria was similarly likely (Martin 2011, 248). ${ }^{18}$ Nevertheless, such (over-)simplification goes a long way towards explaining why a profession that prizes impact often sneers at "Impact."

Many of these complaints about overly-linear impact measurement during REF2014 are recognized in the Stern Review (2016, 16-17, 22-23), and are set to be addressed for REF2021. Impact will be linked to a scholar's body of research in future, rather than a particular "output" (HEFCE 2017b, 9). And pre-2014 Case Studies will be eligible for re-development, provided that the claimed "new" societal/economic impact occurred post-2013 (HEFCE 2017b, 7). Nonetheless, the emphases on demonstrable change, clear links to an individual scholar's body of sufficiently-excellent (by REF criteria) publications produced within a certain time period, and meaningful new effects within the latest REF cycle remain. And addressing one set of distortionary incentives creates as others, as will also be discussed below.

\section{The Limitations and Distortions of "Applied” Research}

The next major criticism of the Impact Agenda is that it privileges close-to-market and close-topolicy research. The UK government does not, of course, tell academics in British universities what to research, except through grants available for projects that address questions that it particularly seeks answers to. But given the five-year REF timetable and criteria that privilege measurably improved economic performance or social benefits, the Impact Agenda rewards research that can deliver "applied" payoffs quickly, potentially distorting incentives and skewing research questions (Ní Mhurchú et al. 2016, 68). Applied research rests, however, on core, foundational science that - as a non-discriminatory public good that does not deliver exclusive returns to a private investor - is systematically under-provided by the private sector (hence the long-recognized need for state and/or philanthropic support). ${ }^{19}$ Applied research that the REF incentivizes academics to produce, therefore, is also the kind of research that the private sector is best at producing anyway. The underlying core science that marketable applications build upon, meanwhile, and which is highly impactful eventually, is least likely to be provided by the private sector but is also less likely to be rewarded by the Impact Agenda. Of course, if an enterprising 
scholar can demonstrate how marketable/policy-implementable outcomes followed from their underlying core science, then they will be amply lauded by the REF - but, as discussed above, this may be difficult. As noted earlier, TRIP surveys hint that the Impact Agenda's introduction between 2011 and 2014 may have induced UK-based IR scholars to self-identify as conducting a larger share of "applied" research, although such data is hardly conclusive thus far. Either way, REF2021's move to 25 percent "impact" and 60 percent "scholarly excellence" (compared to 20 percent and 65 percent respectively in REF2014) will further shift the incentive structure in this direction.

The REF approach to "Impact" measurement may also undervalue reflective, critical approaches - and the humanities in general - vis-à-vis the natural sciences (Olmos-Peñuela, Benneworth, and Castro-Martinez 2015; Molas-Gallart 2015). The biomedical sciences may tell us how to clone mammals; philosophy, history, theology, geography, sociology, psychology and more besides, meanwhile, can help us understand this innovation and decide whether to use it. Similarly, a strategic studies scholar may calculate - based on a database of past COIN campaigns - the proportion of local civilians who need to be killed to defeat an insurgency, and to weigh that outcome against associated strategic risks (blowback, for example). Different scholarship is necessary, however, to understand whether the overall approach is defensible. Critical approaches may not tell us how to make or do something, but they are vital in appraising societal consequences. Again, if a scholar can write an Impact Case Study showing how their analysis of biomedical or military ethics has changed government thinking on whether to clone humans or raze insurgent villages, then they achieve REF-conceived "Impact." But if a tradition of critical thought is simply a diffuse quality of a healthy society, then the scholars engaged in such reflective analysis will have a harder time satisfying the Impact Agenda, even if their research and teaching is a key part of the social fabric (Weiss 1979, 429-430; Dunn 2015; Ní Mhurchú et al. 2016, 65-66).

For both core science and critical reflection, there is of course still plenty of REF reward for research that is simply excellent scholarship, regardless of its "Impact" implications. Nonetheless, to the extent that "securing" the 25 percent of a Department's REF2021 score that is governed by Impact will necessitate institutional expenditure on activities other than core science - and to the extent that RCUK grant applications require an incorporation of "Pathways to Impact" to succeed - there are necessarily opportunity-costs associated with rewarding one 
behavior at the expense of another. Thus, even when HEFCE et al. provide "separate" funding to support Impact activities, the British public purse is necessarily not providing that same level of funding to some other activity. ${ }^{20}$

The Impact Agenda's prioritization of close-to-market/close-to-policy research can similarly incentivize research into the popular rather than the important. When it comes to curing cancer, for example, these two criteria are likely to benignly align: this is important work that the public and policymakers understand to be so, and thus value. In other fields, however, these two criteria may create tension. Since the Impact Agenda prizes public engagement and social change, a gallery exhibit attended by thousands of visitors and with much media coverage may count as highly "Impactful" (for example). By contrast, research on some highly stable, specialist domain of foreign policy may yield little observable change, little public excitement, and thus little "Impact." Yet the latter may be no less valuable to society than the former, possibly more so. Government policymakers, similarly, focus on immediately pressing priorities, but academics may be best placed to assess (and thus choose to research) the longer-term questions, of possibly greater importance, that will subsequently arise. ${ }^{21}$

Many of the enduring problems of politics are both important and intractable: that is why they are unresolved, continuing targets of research. Experts in these questions arguably have a duty, therefore, to direct research priorities in a way that the general-interest public or multitasking policymakers cannot. Yet if the REF-led incentive is to study topics that entertain the public or immediately address a specific problem faced by policymakers - because of the associated "Impact" - such intractable-yet-important questions may go under-studied. This is a particular issue in fields such as History: "boring" analysis of past financial crises or political movements can shape our understanding of our current social situation, but if the public wants to be tantalized by the salacious private lives of bygone royalty, say, work on the latter may be excessively rewarded by the Impact Agenda. Science should of course be guided by intellectual curiosity (Phillips 2010, 448) and social need. There is also value in engaging the general public with scholarly research. It is important, however, that curiosity-led research does not solely become the research of curiosities. ${ }^{22}$

\section{Impact and the Circumvention of Academics' Intellectual Property}

A third major critique of the Impact Agenda relates to its potential to further erode academics' 
property rights and become exploitative. This comes against a backdrop of the West's general weakening of salaried labor and Britain's widening wealth gap (Blagden 2015b; Inman 2016). The Impact Agenda effectively mandates academics to undertake consultation activities pro bono, while professionals in any other field sell their expertise for commensurate remuneration. Media commentary and other forms of public engagement similarly compensate academics only rarely. Scholars have in effect been told to hand over their private human capital for use by profit-making businessmen or vote-winning politicians free-of-charge. The REF does not "force" scholars to become management consultants, political advisers, or television personalities, of course. But it incentivizes such behaviors through the implicit threat of job insecurity - UK universities hire and retain "REF stars" over others, with such "stardom" now having a linkage to Impact - rather than through enhanced remuneration. Of course, part of most scholars' human capital has been accrued through state-subsidized education, so it is not unreasonable that they owe some of it to the public good - but that is also true of investment bankers or corporate lawyers. Private-sector professionals quite rightly do not believe that they owe their services to the state pro bono in perpetuity, contending instead that much of their expertise and wealthgeneration owes to private investment of time and effort, thereby meriting generous compensation. $^{23}$

This is not to rail against private property or argue that high-skill professionals in any sector should not be well paid, but simply to observe that academics are high-skill professionals whose private return to such human capital is paltry compared to other sectors with stronger private property rights. Of course, academics are used to the weak property rights associated with the creation and dissemination of core science: diffuse, public knowledge yields diffuse, public ownership of academics' generated wealth. Academia is a privileged profession with other associated benefits that attract talented participants willing to eschew superior remuneration packages. But the Impact Agenda, by incentivizing the transfer of academics' expertise via a format other than the publication of core science, effectively takes scholars' human capital and turns it to the benefit of private property rights - via consultation, spin-off technology, policy advice, popular media writing, and so forth. The academic who provided the underlying expertise often has no claim to commensurate private remuneration. ${ }^{24}$ This is not just a hypothetical risk, moreover: UK universities' "Impact Support" offices now transmit constant flows of requests for consultation from both public and private-sector organizations, making 
clear that the reward is not remuneration but a potential strengthening of faculty members' “impact" files, while probation/promotion committees pay close attention to such activity.

In short, the Impact Agenda risks turning academics - or at least those without the prominence or seniority to bargain otherwise - into consultants who are expected to serve the private ends of others for free. The forthcoming REF2021 assessment criteria, whereby "impact" can be linked to a body of work rather than a specific "output" (HEFCE 2017b, 9) - while reducing the unrealistic linearity discussed above - may exacerbate this problem of simply being expected to work as pro bono consultants, illustrating that there are few easy fixes: ameliorating one set of distortionary incentives creates another. If this drives academics to use participants in their "Impactful" research in a way that is itself exploitative, then the problem is compounded (Allen 2014). And if junior scholars have foregone research time to conduct impact activities, then it is compounded again. This may be palatable when the beneficiary is UK state policy that in turn benefits the whole British public, but when the beneficiaries are private companies and/or powerful individuals, it is particularly questionable.

\section{Impact and the Vulnerabilities of the Lone Scholar}

Fourth, there is the more general problem of the atomization and relative institutional weakness of academics vis-à-vis "competitors" in the policy impact "space" (Himmrich 2016, 2). Thinktanks benefit from proximity to government, inside connections to policymakers and forthcoming decisions, media access, and from being purpose-built for providing "customer-led" policy analysis quickly. They can thus sometimes be a conduit for rigorous academic research into policy, but are also a regular obstacle to that outcome (Williamson 2011). The journalistturned-pundit "commentariat," meanwhile, may lack expertise in any given specialist field, but benefit from personal connections and from being well placed to write or say anything that a newspaper or broadcaster asks for at short notice.

Taken together, this Westminster-centric "punditocracy" - like its Washington-Beltway counterpart - often leaves academics behind the curve, only discovering that their area of expertise is a focus of policy/media attention after think-tank analysts and pundit-columnists have already colonized the issue. An academic with only a non-specialist press officer for company, however excellent, may struggle to gain media or policy facetime despite their superior specialist expertise. ${ }^{25}$ And the think-tank/punditry communities have a vested interest in 
keeping it that way, hence their closed-shop operation and sustainment of pernicious myths about academics' inability to constructively engage with the public or policymakers. As Ezra Klein (2014) half-honestly puts it, "It would be a disaster for our profession [journalism] if academics became good at communicating what they know" - the honest part being that it could be disastrous, and the self-interestedly dishonest part being that academics are universally poor at public/policy communication (Preble 2017, 280).

Of course, a few academics do break into the circles of government advisers and/or media columnists, but can then themselves become insiders with a vested interest in preserving the closed shop (Himmrich 2016, 2). Government's understandable desire to hear "sound" academics who "get" the policy environment can see only a regular clique of scholars consulted (Freedman 2017, 265). Breaking into such circles is also problematic; biases towards sourcing academics from Southeastern (particularly London-based) institutions and senior figures prevail. $^{26}$

These challenges are exacerbated by the rise of social media and its relationship to policy commentary. The likes of Twitter and Facebook - the former, in particular, given its public micro-blogging format - allow academics to raise their public profile and disseminate their work within and beyond their specialist communities. Yet in the echo-chamber cacophony of 140character commentary (Daykin 2016; Hoffman 2016), academics' specialist expertise can easily get eclipsed - particularly when number of "followers," which tends to benefit celebrity journopundits rather than scholars, is taken as a proxy for credibility. Social media may have enriched the marketplace of ideas, but it has also saturated it. "Click-bait" pundits with less insight but greater "presence" often crowd-out academic voices - a perverse consequence of the "democratization" of information, under which many of the general public regard themselves as equally knowledgeable - regardless of academics' specialist expertise (Nichols 2017). Scholars around the world must counter this, especially in this age of skepticism over the existence and value of knowledge (Nichols 2017; Mance 2016; Krauss 2016). The heavy social media presence required by scholars who seek to break into the punditocracy can itself become a time sink, moreover, with perilous opportunity-costs for junior academics in need of blue-chip publications to establish their research credentials. And it can expose academics to personal abuse from those who disagree with their conclusions (Phipps 2014), or disproportionately reward those most willing/able - thanks to various forms of privilege - to brag about their achievements. In the 
recent tide of "anti-expert" sentiment, this combination of marginalization and vilification looks unlikely to improve anytime soon.

\section{The Ethical Quandaries of Closeness to Government}

Fifth, the pursuit of policy influence raises ethical questions over scholars' intellectual integrity and the possible consequences of a "customer-led" (that is, government-serving) academic role (Hill 1994; Zambernardi 2016). Gaining REF-privileged access to policymakers may incentivize telling them what they want to hear. At the very least, trying to achieve impact may involve difficult deliberations over how far to temper academic findings for policy "fit." When faced with a policy with which they disagree (not unlikely), a scholar may choose to oppose it outright, via either contentious critique or outright paradigmatic rejection. This is admirable, but unlikely to reverse a course with the power of state institutions and ministers' personal political capital behind it (Lloyd 2016). Alternatively, they may seek only to finesse the proposed policy, suggesting small, achievable modifications within consensual acceptance. This may yield concrete improvements to policy, but may also be intellectually dishonest and even open to charges of corruption. Academic engagement with Brexit has thrust this trade-off into stark relief for many UK-based social scientists. Neither route has an unambiguously superior impact on the sum of human welfare; each context must be judged (Nutley, Walter, and Davies 2007, 11-12). But scholars have a duty to remain true to their research findings (Preble 2017, 280). The reputational damage of being otherwise could be particularly problematic for an early-career scholar, meanwhile, whereas a senior professor may not care that colleagues have dubbed them a policy "hack."

Similarly, a scholar may choose to provide either abstract generalities or specific answers in addressing a policy consultation. The latter may be more likely to yield a policy change, and thus "Impact," but it may also (by working within terms set by the government of the day) be implicitly partisan-political, another quandary. A scholar may likewise choose to "go along" with a particular policy in the present, in the hope of becoming an "insider" capable of exerting beneficial influence in the future, but this too carries questions over integrity. A scholar may simply hope that their "big idea" percolates through to policy eventually, without purposeful steps to help it on its way, but that may reflect false optimism about the meritocracy of political decision-making. That said, political winds $d o$ change - consider the demise of COIN-centrism 
and return of state-based thinking in UK defense policy, for example - so sticking to one's intellectual guns may ultimately be rewarded by a more receptive climate for achieving influence.

Conversely, there may be research insights that scholars do not want to have "impact," again for ethical reasons. Identifying that the success of past COIN campaigns rested on killing a certain proportion of the local population may be a valuable scientific discovery, for example, but the scholar in question may have no desire to see it turned into policy - and the fact that it might be could itself have a chilling effect over research priorities.

Involvement with policy can raise an academic's profile, but perceived closeness to government can also harm scholarly standing (Freedman 2017, 263-264), particularly if they are seen as conveniently finding the answers that policymakers want to hear or fueling/enabling otherwise-undesirable decisions. Ultimately, even when dealing with sympathetic and principled individual policymakers who begin with the intention of rigorous evidence-based policy evaluation, that process still routinely gets compromised (Hallsworth, Parker, and Rutter 2011) and, like any of us, policymakers are most likely to be reassured by voices that agree with them (Preble 2017, 275-276). Academics should thus expect to get tactically and politically "used" in their dealings with government (Weiss 1979, 429), losing their ownership and "voice" once their evidence/advice is submitted and turned to the ends of powerful institutions/individuals with their own agendas. The same can apply to quotation/manipulation by journalists. Neither can be compelled by scholars, however well-connected, to align with their presentation of the evidence (Nutley, Walter, and Davies 2007, 18-20). The question that guides whether being used in this way is worthwhile, however, is: can one still achieve some good along the way?

\section{Impact "Tactics"}

The previous section documented five downsides to policy engagement in general and the UK Impact Agenda in particular. Accepting the overarching premise of the article, however - that policy influence remains both a socially valuable and personally rewarding aspect of IR scholarship - this section progresses to consider the achievement of impact, building on the avenues discussed earlier. Along the way, it considers ways to minimize or guard against some of the pitfalls discussed above.

Achieving policy influence - and its prerequisite, policy access - is not necessarily 
straightforward (Himmrich 2016, 2). Beyond HEFCE/RCUK funding for "Knowledge Exchange" activities, achieving such influence is usually left to individual academics' initiative. As Ben Goldacre (2016) puts it, “[t]his is part of being a public servant, but it's a practice without a...toolkit, handbook or diploma." The ESRC (2017a) does attempt to provide such a "toolkit," to be fair, but the general point stands that simply having valuable theory, data, and methodology does not guarantee that it will be heard by policymakers (Edgerton 2017). Assuming that scholars can navigate the UK government's recent ban on publicly-funded "lobbying" (HM Government 2016c; Goldacre 2016) - a ban that government itself seemingly has no intention of abiding by, as it continues to encourage academic input - and with the Impact Agenda only set to grow in prominence, this will remain a challenge for many academics. And it will be particularly challenging for earlier career, lower profile scholars who are not yet actively sought out by policymakers.

Accordingly, this final section reflects on the "operational-level" tactics of achieving impact for those at "not-yet-famous" career stages. It does not claim particular expertise, and certainly lacks the "impact experience" of a senior scholar (Goldacre 2016). The author benefits, however, from having assessed the consultation responses for two UK White Papers whilst working in government prior to securing an academic post, and therefore has some insight as both a "submitter" and a "receiver" of scholarly attempts at policy engagement. What follows is at times unvarnished and pragmatic, rather than aspirational and idealistic, but that does not mean that the latter qualities should not be striven for also. It is also necessarily reflexive and skewed by personal biases, so should be taken as one perspective among many. ${ }^{27}$ Many of the points apply to influencing any government policy machinery, although some - such as the openness of Parliamentary Select Committees' public calls for evidence - are particular features of the British system.

First, simple, well-packaged, jargon-free consultation responses and evidence submissions with potentially "actionable" implications are essential (Byman and Kroenig 2016, 298-299; Wiers 2017, 3). Busy officials will be eager for academic input - lacking deepspecialist expertise themselves, they are grateful when it lands in their lap - but not if they have to decrypt a dozen pages of dense, jargonistic text dealing in abstract generalities (Walt 2005; Avey and Desch 2013; Talbot and Talbot 2014). Number paragraphs, keep sentences short and simple, address the policy area/consultation requirements directly, and include a bulleted 
executive summary if going beyond a couple of sides (depending on how complex the points being conveyed are, and unless explicitly invited otherwise by a relevant official). Include some reference to how your advice follows from your research. This will enhance its credibility, and at least on REF2014 rules - is necessary for it to "count" towards an Impact Case Study.

Second, deploy your "line" across many separate platforms: Select Committee evidence calls, departmental consultation responses, media commentary, and so forth. This increases the chances of your perspective subsequently being incorporated into policy (Nutley, Walter, and Davies 2007, 61-66; Goldgeier and Jentleson 2015). A departmental consultation response may get ignored (for example), due to deviation from the government's preferred angle or mere capacity constraints, but if your perspective is subsequently favored by a Select Committee report or receives high-profile media coverage (Freedman 2017, 266-267) then all stakeholders will subsequently be obliged to take note. The Parliamentary webpages of relevant Select Committees are good places to look for “regular" engagement opportunities, via inquiries' calls for evidence. Departmental consultation and op-ed/media opportunities require careful tracking because they come along irregularly as a particular policy comes under review or a particular issue hits the headlines. Building long-term networks and making contacts beyond Parliament, moreover, can enable advance warning of forthcoming policy impact opportunities and generate more "embedded" influence relationships outside the mechanistic cycle of Select Committee inquiries (Oliver et al. 2014, 4; Himmrich 2016, 4-5). Being part of the policymaking process allows superior influence opportunities than merely attempting to "bolt onto" it at some point in the decision cycle (Rutter 2011).

Third, do not attempt to achieve a wholesale reversal of government policy - or at least be aware that such an attempt is unlikely to succeed (Preble 2017, 275). Government has a democratic mandate and, unless you are a scholar with the public profile of Paul Krugman or Niall Ferguson, practically all of the institutional and personal political power. Instead, seek kernels of common ground (Goldacre 2016) with the aim of constructively changing one or two aspects of a policy. Government normally has too much political capital invested in a policy to abandon it entirely, but also wants policies to succeed. Harassed non-specialist officials are often glad of the help (Gavin 2017, 271), so academics' efforts to improve policy in pragmatic, feasible ways have a good chance of being adopted. Of course, if you have no common ground with proposed policy, there is still value in saying so - large-scale dissent can eventually sway 
wavering decision-makers, and you may be well placed to claim the mantle of righteous resistance in the hope of an eventual change. But remain realistic that prospects for achieving meaningful progressive change via this latter route will come along rarely, if at all.

Fourth, try to anticipate the news cycle using a combination of media indicators and your specialist expertise. One area of academic relative advantage vis-à-vis non-specialist commentators is a deep knowledge of upcoming policy decisions, reviews, debates, crises, and so forth. Following rumors of forthcoming decisions via Twitter and suchlike can augment this knowledge. Pitching an op-ed about an issue is much more effective if done the week before publication of a policy review (for example) than if you only pitch once the review has hit the headlines and been "colonized" by journo-pundits. Conducting policy-relevant research, and advertising it as such to decision-makers, is similarly of little use once a policy question has been settled (Byman and Kroenig 2016, 298-299; Freedman 2017, 267).

Fifth, utilize the profile-raising UK impact channels that are readily available. The Royal Society, Arts and Humanities Research Council (AHRC), and ESRC all offer "Impact" training, mentorship, and support, although the schemes differ in their openness, access, and format (AHRC 2015; ESRC 2016, 2017a, 2017b; Royal Society 2016). The U.S. "Bridging the Gap" Project (2015b) has a policy/media engagement program specifically to train foreign-policy scholars (Goldgeier and Jentleson 2015); it is American-centric, but open to overseas participants, as are certain other U.S.-based initiatives (Andrews et al. 2015). Press officers and "Impact Support" staff at universities are often excellent yet under-utilized. Leverage "political" allies - think-tank colleagues, media contacts, sympathetic backbench MPs, and so forth - who may have access and profile-raising potential that you lack (Sebba 2011; Goulden 2011; Mendizabal 2011; Himmrich 2016, 4), but avoid trying to duplicate their functions (Gavin 2017, 273). Using academia-friendly media outlets, such as The Conversation, can raise your profile in a way that makes mainstream media op-eds or policymaker access more likely - though do not expect a friendly hearing in Whitehall if you have already trashed a policy in print, and neither are mainstream op-eds easily secured or necessarily noticed. Op-ed writing for a large audience requires a thick skin, moreover, and the online "comments" sections are best avoided on all but the sunniest days.

Sixth, be prepared to be "blindsided" by events - and as far as possible, caveat your policy interventions to avoid misleading policymakers and/or subsequently discrediting yourself. 
This is a particularly significant danger when engaging in prediction/forecasting, because even with the deepest subject-matter expertise, complex contingencies can still arise that scholarship did not have sufficient prior data to incorporate yet with which policymakers must contend (Jervis 1999; Wiers 2017, 284-285; Gavin 2017, 270-271). Academics are rarely in a position to say what will work/happen; the best we can usually aspire to is to help policymakers and the public better understand complex systems (Gavin 2017, 272-273; Freedman 2017, 267), while suggesting what may work/happen (Bassey 2013). This nuancing is hard to do within the tight length constraints of a typical newspaper column or radio soundbite. In one op-ed, for example, this author started from the premise of further cuts to the UK defense budget (Blagden 2015c)...just before the then-Chancellor of the Exchequer, George Osborne, ring-fenced all national security spending in a bid to position as a statesmanlike premier-in-waiting (Winnett 2015; Dorman, Uttley, and Wilkinson 2016). ${ }^{28}$ While hardly terminal to the broader arguments of the piece, this gaffe could have been ameliorated with less hubristic, better caveated analysis.

Avoiding such pitfalls involves avoiding hasty, slapdash writing while thinking through potential second-order contingencies. It is also a matter of resisting editors' demands for tooconcise, excessively provocative, inadequately caveated "click-bait": their incentive is to generate traffic and reaction, yours is to produce a piece with enduring credibility. These points apply in policy consultancy, too, as well as media commentary. That said, the carefully caveated circumspection of many academics is also what makes their input less appealing to policymakers/editors eager for decisive, deterministic advice/views (Preble 2017, 276-278).

\section{Conclusion}

Public impact through policy influence remains a vital and admirable aspect of a scholarly career, and a particularly relevant one in the social sciences. Indeed, defined broadly enough to include the positive social consequences of teaching and core science, impact is the goal of scholarship - even conceding that the UK "Impact Agenda" has created distortions that sometimes hinder the attainment of this end. The pursuit of influence can be dispiriting and occasionally perilous, particularly for junior scholars. But it remains worthwhile, for both altruistic-societal and personal-instrumental reasons, and never more so than in an age of hostility to theory- and evidence-based public discourse (Hoffman 2016).

The Impact Agenda is improvable, of course, and scholars/institutions are not without 
agency. Assessment of "Institutional Impact" has been deferred beyond REF2021 in response to universities' lobbying over the associated labor burden and inevitable inaccuracies (Else 2017), while the move to decouple Impact Case Studies from specific "outputs" - another modification long advocated by the academic community - should reduce the contrived artificiality of the supposed link between research and wider-world effects. Greater diversification between/within academic departments could enable some institutions/individuals to focus more on policy, say, while clarity over probation/promotion criteria can reduce the dangers to scholars' careers of getting the research-versus-impact balance wrong. All such fixes create trade-offs and incentives, however. The deferral of "Institutional Impact" leaves the onus with individual scholars, atomized/weak though they are. "Impact" may be decoupled from specific "outputs," but it will still - unavoidably, if measurement is to be meaningful - be connected to a body of work over certain time parameters, incentivizing certain forms of behavior. Diversification of departments would risk further siloing the profession between "researchers," "wonk-pundits," and "bureaucrats," whereas the Agenda's commendable intention - and the behavior that it rewards is for knowledge's creators (researchers) to also be those who maximize its public impact (wonkpundits) and manage the institutions in which it is created (bureaucrats). And prescribing a specific amount of "impact" against a specific quality/quantity of "outputs" for staff advancement would risk stifling the excellence borne of flexibility; alternative incentives - such as financial bonuses - could destroy collegiality, meanwhile, in departments where different staff contribute different strengths (disproportionate teaching/administrative burdens, for example). In short, while the REF and its Impact Agenda can and should be iteratively refined, such an exercise in measurement - while defensible, given its demands on the public purse - will always produce distortions of one kind or another.

To reduce the perils of early-career policy engagement, therefore, two sets of questions must be answered before pursuing "impact." First, what - if any - ethical trade-offs between intellectual integrity and substantive influence might you be expected to make? Second, what are your ultimate expectations of reward? Fame, riches, and wholesale changes in policy are unlikely outcomes. But if you are willing to apply some aspect of your research to refining a specific element of a public debate in a way that is of concrete use to decision-makers, in exchange for only diffuse and modest personal benefits, your ambitions may be more readily met.

Ultimately, "operational-level" influence strategizing aside, the foundation of any 
scholar's impact profile will remain the quality of their underlying research, defined by the scale of the questions tackled, the persuasiveness of the arguments advanced, and the rigor with which they are interrogated (Flinders and John 2013). This naturally remains the responsibility of individual scholars, and cannot be addressed here. This article will have served its purpose, however, if it goes some way towards building upon such foundations by promoting, demystifying, facilitating, and de-risking the process of policy "translation" of scholars' underlying discoveries.

\section{Notes}

${ }^{1}$ The other devolved British nations - Scotland, Wales, and Northern Ireland - have separate funding settlements, although they use the same REF to assess universities' research performance.

${ }^{2}$ In 2015-16, for example, the UK Research Councils dispensed $£ 2.67 \mathrm{bn}$ of project-specific funding, but only $£ 153.2 \mathrm{mn}$ of that went to the Economic and Social Research Council (ESRC) and a mere $£ 98.3 \mathrm{mn}$ to the Arts and Humanities Research Council (AHRC) (HM Government 2014b, 10).

${ }^{3}$ The REF - and its predecessor, the RAE - is a UK-wide assessment exercise conducted jointly by the Higher Education Funding Council for England (HEFCE), the Scottish Funding Council (SFC), the Higher Education Funding Council for Wales (HEFCW), and Northern Ireland's Department for the Economy (DfE-NI). It occurs once every four-to-seven years, and is used to rank the research outputs of all UK academic departments in receipt of state financial support to determine their QR "Block Grant" public research funding for the subsequent "REF cycle." Block Grants are specifically linked to REFassessed research profile - universities also receive some public financial support based on their teaching profile, which is now assessed via a complementary Teaching Excellence Framework (TEF) (HEFCE 2017a; Ashwin 2016), albeit with a fee-cap irrespective of TEF scores (BBC 2017).

${ }^{4}$ Technically, universities' REF performance is assessed at the level of discipline-specific "Units of Assessment," not simply that institution's established academic departments. Such UoAs broadly corresponded with departmental alignment, however; REF2014 had 36 (REF 2012c), while REF2021 drops to 34 (HEFCE 2017b, 16).

${ }^{5}$ These panels are not uncontentious: they form a huge labor burden, cannot conduct truly-anonymous review (since they are assessing already-published research), and often see only a single non-specialist review a submission (Sayer 2014).

${ }^{6}$ HEFCE funds English institutions (HEFCE 2016a). SFC, HEFCW, and DfE-NI similarly fund the other devolved nations. 
${ }^{7}$ Emphasis added.

${ }^{8}$ Questions remain over the "portability" of scholars" "REF-able" publications between institutions, both at REF2021 and beyond (HEFCE 2017b). Permitted in REF2014, a REF2021 rule change could have major implications for scholars' career mobility.

${ }^{9}$ Tony Blair was an ideologically-committed interventionist, of course, but his Iraq impetus came despite - not from - the national-security bureaucracy.

${ }^{10}$ The University of Exeter's Strategy and Security Institute (SSI) is a member of the Ministry of Defence's (MOD’s) Niteworks consultancy grouping, for instance: http://www.exeter.ac.uk/strategy/news/ [Accessed 30 August 2016]. The Department for International Development (DfID), the MOD, the Foreign Office and Cabinet Office all regularly consult invited academics. Of course, heavy reliance on consultants has drawbacks (Provost 2012; The Telegraph 2015). ${ }^{11}$ These two organizations have both welcomed the author to present research over the last five years.

${ }^{12}$ Lower-profile specialist outlets such as The Conversation (2016) are more readily accessible to aspiring academic contributors, of course.

${ }^{13}$ The Royal United Services Institute's Project on Nuclear Issues stands out, for example: https://rusi.org/projects/uk-project-nuclear-issues. So did Chatham House's European Security and Defence Forum: https://www.chathamhouse.org/about/structure/international-securitydepartment/european-security-and-defence-forum-project [both URLs accessible 1 November 2017]. ${ }^{14}$ The author has academic colleagues who have made both of these transitions.

15 The underlying research "output" was permitted to have been produced prior to the REF2014 cycle, provided (a) that its demonstrable "Impact" effects did take place in the REF2014 cycle and (b) that the underlying "output" had been produced at the same university now claiming the Impact Case Study. ${ }^{16}$ Disproportionate recognition for the already-senior/-prominent is itself a potentially discriminatory consequence of "Impact."

${ }^{17}$ Some impact advocates contend the opposite: that "influence" may count as merely impressing a decision-making practitioner, but to "make a difference" - to have true "impact" - should indeed require the demonstration of positive change (Francis 2011, 5). However, this neglects the possibility for progressive outcomes to arise from the absence of observable change - positive policy stasis - achieved through scholarly influence. Accounting for positive impact only in terms of observable change holds progressive influence hostage to selection bias.

${ }^{18}$ Such problems may be reduced with more sophisticated measurement methodologies, particularly through a move away from weighting observed change so heavily in impact assessment (Upton, Vallance, and Goddard 2014; Morton 2015; Samuel and Derrick 2015; Ní Mhurchú et al. 2016, 69-70). 
${ }^{19}$ For a basic discussion of private-sector under-provision of public goods, and an associated explanation of the case for state support to solve the market failure/collective action problem, see Varian (2003, 643666).

${ }^{20}$ This opportunity-cost critique similarly applies to the paying of "Open Access" publishing fees.

${ }^{21}$ For the controversial view that policymakers do indeed know best, and that scholars should align their research priorities with politically-mandated questions, see Moono (2012).

${ }^{22}$ A recent press release from a major British research university hailed one of its research projects as "celebrity-endorsed," to the consternation of many UK academics. The project in question has clear scholarly and environmental value, and acclaim from high-profile public figures is no bad thing, but recognition by film/television personalities becoming a criterion for academic merit has potentially chilling implications.

${ }^{23}$ Whether the scale of these professions' private wealth concentrations can be justified - given the quantity of other people's human capital that goes into producing their earnings (Blagden 2015b) - is a different question entirely.

${ }^{24}$ Spinoff companies and technological patents may provide a partial exception in fields such as engineering, of course. Nonetheless, the point stands for policy advice and the dissemination of core science.

${ }^{25}$ One of The Guardian's acclaimed columnists recently lambasted the Astute-class submarines - nuclearpowered but not ballistic-missile-carrying boats (SSNs) - as being the overdue, over-budget successor to the Vanguard-class ballistic missile submarines (SSBNs) (Jenkins 2016), displaying an unfortunate lack of expertise. Similarly, one of the New Statesman's regular pundits recently lambasted UK Trident for not deterring 9/11: forgivable illogic, perhaps, given that the national-security "authority" in question transpired to still be an undergraduate (Young 2016). Select Committees' hearings of "expert" oral evidence can be equally galling when stacked with generalist think-tankers, rather than university-based specialists.

${ }^{26}$ Privileging senior figures for their expertise in an area is completely appropriate. It becomes problematic, however, when senior figures do not in fact have particular expertise in an area, but are simply famous "go-to" insiders.

${ }^{27}$ For a similar perspective based on a junior academic's time in a policy role, making similar points, see Wood (2012).

${ }^{28}$ It is possible, of course - though hardly likely - that the author's recommendations themselves swayed Osborne, which would make for a truly remarkable Impact Case Study if provable! That said, even this 
"commitment" to defense spending still relied on questionable accounting (House of Commons Defence

Select Committee 2016).

\section{Acknowledgements}

The author thanks Sergio Catignani, Rob Freathy, Patrick Porter, the anonymous reviewers, and especially Helena Mills for invaluable comments/discussion. He also thanks the University of Exeter for "Impact Accelerator" funding, and the UK Economic and Social Research Council [Grant Number ES/H015906/1] for its support of an intra-PhD policy secondment.

\section{References*}

* All cited URLs accessible as of 1 November 2017.

AHRC. 2015. Engaging with Government. Available from:

http://www.ahrc.ac.uk/funding/opportunities/current/engaging-with-government/.

Allen, ANSGAR. 2014. "Who benefits from the Impact Agenda?" Times Higher Education Supplement, 6 November. Available from: https://www.timeshighereducation.com/comment/opinion/who-benefitsfrom-the-impact-agenda/2016732.article.

ANDREWS, LENA, REBECCA FRIEDMAN LISSNER, JULIA MACDONALD, JACQUELYN SCHNEIDER, AND RACHEL WHITLARK. 2015. "Getting involved in policy: an overworked grad student's guide." WarOnTheRocks.com, 6 May. Available from: https://warontherocks.com/2015/05/getting-involvedin-policy-an-overworked-grad-students-guide/.

ARIN, KUBILAY Y. 2014. "The Impact of Neoconservative Think Tanks on American Foreign Policy." $e$ International Relations, 26 May. Available from: http://www.e-ir.info/2014/05/26/the-impact-ofneoconservative-think-tanks-on-american-foreign-policy/.

ASHWIN, PAUL. 2016. "'Bizarre' TEF metrics overlook so much about teaching excellence." Times Higher Education Supplement, 7 June. Available from:

https://www.timeshighereducation.com/blog/bizarre-tef-metrics-overlook-so-much-about-teachingexcellence.

Avey, Paul C., AND Michael C. Desch. 2013. "What Do Policymakers Want From Us? Results of a Survey of Current and Former Senior National Security Decision Makers." International Studies Quarterly 58(2): 227-246.

BASSEY, MICHAEL. 2013. "The current enthusiasm for evidence-based policy needs to be met with a greater degree of methodological caution." LSE Blogs, 11 April. Available from:

http://blogs.lse.ac.uk/impactofsocialsciences/2013/04/11/the-current-enthusiasm-for-evidencedbased-policy/.

BBC. 2016. "A guide to Trident and the debate about its replacement." 18 July. Available from: http://www.bbc.co.uk/news/uk-politics-13442735.

BBC. 2017. "Theresa May pledges help for young on student fees and housing." 1 October. Available from: http://www.bbc.co.uk/news/uk-politics-41456555.

Bellamy, AleX J., AND Paul D. Williams. 2011. "The New Politics of Protection? Côte d'Ivoire, Libya and the Responsibility to Protect." International Affairs 87(4): 825-850.

BLAGDEN, DAVID. 2009. "Strategic Thinking for the Age of Austerity." RUSI Journal 154(6): 60-66. - 2015a. Thinking the Unthinkable: The MOD as an Indicative Case Study (University of Exeter Evidence to the House of Commons' Defence Select Committee). London: Parliament, pp. 9-13. Available from: http://data.parliament.uk/writtenevidence/committeeevidence.svc/evidencedocument/defencecommittee/an-sdsr-checklist-of-potential-threats/written/22550.pdf. 
—. 2015b. "Labour must abandon the dangerous language of 'wealth creators'." New Statesman, 20 May. Available from: https://www.newstatesman.com/politics/2015/05/labour-must-abandon-dangerouslanguage-wealth-creators.

—. 2015c. "David Cameron's unstrategic defence review." The Spectator, 20 June. Available from: http://blogs.spectator.co.uk/2015/06/david-camerons-unstrategic-defence-review/.

—. 2017. "Britain and the World after Brexit." International Politics 54(1): 1-25.

BRENNAN, JOHN. 2015. "Explainer: how much state funding to universities get?" OpenLearn, 9 June. Available from: http://www.open.edu/openlearn/people-politics-law/politics-policy-people/societymatters/explainer-how-much-state-funding-do-universities-get.

BRIDGING THE GAP PROJECT. 2015a. Funding and Fellowship Information. Available from: http://bridgingthegapproject.org/resources/funding/.

—. 2015b. International Policy Summer Institute. Available from: http://bridgingthegapproject.org/programs/ipsi/.

Brodie, BernARD (ed.). 1946. The Absolute Weapon: Atomic Power and World Order. New York: Harcourt.

Bull, HedLeY. 1977. The Anarchical Society: A Study of Order in World Politics. New York: Columbia University Press.

Byman, DANIEL, AND MATTHew KRoenig. 2016. "Reaching Beyond the Ivory Tower: A How To Manual." Security Studies 25(2): 289-319.

CABle, Vince, AND DAVID WilletTS. 2010. Higher Education Funding for 2011-12 and Beyond (Letter to Tim Melville-Ross, 20 December). London: Department for Business, Innovation and Skills. Available from:

https://www.gov.uk/government/uploads/system/uploads/attachment_data/file/32406/10-1359-hefcegrant-letter-20-dec-2010.pdf.

CAREY, CAROL. 2014. "Beyond the Academy: The Impact Agenda and You." Jobs.ac.uk, November. Available from: http://www.jobs.ac.uk/careers-advice/working-in-higher-education/2279/beyondthe-academy-the-impact-agenda-and-you.

DAHRENDORF, RALF. 1968. "Uncertainty, Science, and Democracy" in Ralf Dahrendorf (ed.), Essays in the Theory of Society. Stanford: Stanford University Press, pp. 232-255.

DAYKIN, JERRY. 2016. "Could social media be tearing us apart?" The Guardian, 28 June. Available from: https://www.theguardian.com/media-network/2016/jun/28/social-media-networks-filter-bubbles.

Dorman, ANDREW M., MATtheW R. H. UtTLEy, AND BENEDiCt WilKinson. 2016. "The Curious Incident of Mr Cameron and the United Kingdom Defence Budget: A New Legacy?" Political Quarterly 87(1): 46-53.

DunLEAVY, PATRICK, AND DOMINIC MUIR. 2013. "Parliament bounces back - how Select Committees have become a power in the land." LSE Blogs, 19 July. Available from: http://blogs.lse.ac.uk/politicsandpolicy/parliament-bounces-back-how-select-committees-havebecome-a-power-in-the-land/.

DunN, John. 2015. "The Impact of Political Theory." Political Studies Review 13(4): 494-499.

Edgerton, BARTON. 2017. "Book review: Evidence-based Policy Making in the Social Sciences: Methods that Matter edited by Gerry Stoker and Mark Evans." LSE Blogs, 22 January. Available from: http://blogs.lse.ac.uk/impactofsocialsciences/2017/01/22/book-review-evidence-based-policymaking-in-the-social-sciences-methods-that-matter-edited-by-gerry-stoker-and-mark-evans/.

ELSE, HOLLY. 2017. "Impact weighting increased in UK's REF 2021." Times Higher Education Supplement, 1 September. Available from: https://www.timeshighereducation.com/news/impactweighting-increased-uks-ref-2021.

ESRC. 2016. RCUK Policy Internship Scheme. Available from: http://www.esrc.ac.uk/funding/fundingopportunities/rcuk-policy-internship-scheme/.

—. 2017. Impact Toolkit. Available from: http://www.esrc.ac.uk/research/impact-toolkit/. 
—. 2017. AHRC-ESRC-FCO Knowledge Exchange Fellowship Scheme. Available from: http://www.esrc.ac.uk/files/funding/funding-opportunities/ahrc-esrc-fco-knowledge-exchangefellowship-scheme-call-spec/.

FARMER, BEN. 2014. "MoD tried to pulp its own Helmand lessons book." The Telegraph, 9 April. Available from: http://www.telegraph.co.uk/news/uknews/defence/10754344/MoD-tries-to-pulp-itsown-Helmand-lessons-book.html.

FINNEMORE, MARTHA, AND KATHRYN SIKKINK. 1998. "International Norm Dynamics and Political Change." International Organization 52(4): 887-917.

FLINDERS, MATTHEW. 2012. "You don't need a weatherman to know which way the wind blows: a response to Peter John on the relevance of political science." LSE Blogs, 25 April. Available from: http://blogs.lse.ac.uk/impactofsocialsciences/2012/04/25/response-matt-flinders-political-science/.

Flinders, MAtThew, And Peter John. 2013. “The Future of Political Science.” Political Studies Review 11(2): 222-227.

FRANCIS, BECKY. 2011. "Increasing Impact? An Analysis of Issues Raised by the Impact Agenda in Educational Research.” Scottish Educational Review 43(2): 4-16.

FREEDMAN, LAWRENCE. 2017. “Academics and Policy-making: Rules of Engagement.” Journal of Strategic Studies 40(1-2): 263-268.

GAVIN, FrANCIS J. 2017. "Policy and the Publicly Minded Professor." Journal of Strategic Studies 40(12): $269-274$.

GILES, CHRIS. 2016. "Theresa May commits to a balanced budget.” Financial Times, 20 July. Available from: https://www.ft.com/content/df2160f6-4e 76-11e6-8172-e39ecd3b86fc.

GOLDACRE, BEN. 2016. "Ban academics talking to ministers? We should train them to do it." Times Higher Education Supplement, 7 March. Available from: https://www.timeshighereducation.com/comment/ban-academics-talking-to-ministers-we-shouldtrain-them-to-do-it.

GOLDGEIER, JAMES, AND BRUCE JENTLESON. 2015. "How to bridge the gap between policy and scholarship." WarOnTheRocks.com, 29 June. Available from:

https://warontherocks.com/2015/06/how-to-bridge-the-gap-between-policy-and-scholarship/.

GOULDEN, CHRIS. 2011. "“We would never try to have an impact for impact's sake alone": the inside view on think tanks and academic research." LSE Blogs, 24 October. Available from: http://blogs.lse.ac.uk/impactofsocialsciences/2011/10/24/partnerships-and-influence/.

Hallsworth, Michael, Simon Parker, And Jill RutTer. 2011. Policy Making in the Real World: Evidence and Analysis. London: Institute for Government. Available from: https://www.instituteforgovernment.org.uk/sites/default/files/publications/Policy\%20making\%20in\% 20 the $\% 20$ real $\% 20$ world.pdf.

HEFCE. 2015. Recurrent Grants for 2015-16. Bristol: HEFCE. Available from: http://www.hefce.ac.uk/media/HEFCE,2014/Content/Pubs/2015/201505/HEFCE2015_05.pdf.

—. 2016a. How we fund research. Available from: http://www.hefce.ac.uk/rsrch/funding/.

- 2016b. Consultation on the second Research Excellence Framework. Bristol: HEFCE. Available from: http://www.hefce.ac.uk/media/HEFCE,2014/Content/Pubs/2016/201636/HEFCE2016_36.pdf.

HEFCE. 2017a. About the TEF. Available from: http:/www.hefce.ac.uk/lt/tef/whatistef/.

HEFCE. 2017b. Initial Decisions on the Research Excellence Framework 2021. Bristol: HEFCE. Available from:

http://www.hefce.ac.uk/media/HEFCE,2014/Content/Pubs/Independentresearch/2017/REF,201701/R EF2017_01.pdf.

HEFCE. 2017 c. Financial Health of the Higher Education Sector: 2015-16 Financial Results. Bristol: HEFCE. Available from: http://www.hefce.ac.uk/media/HEFCE,2014/Content/Pubs/2017/201702/HEFCE2017_02.pdf.

HEFCE et al. 2016. REF impact. Available from: http://www.hefce.ac.uk/rsrch/REFimpact/. 
HICKS, DiANA. 2012. "Performance-based University Research Funding Systems." Research Policy 41(2): 251-261.

HILl, CHRISTOPHER. 1994. "Academic International Relations: The Siren Song of Policy Relevance" in Pamela Beshoff and Christopher Hill (eds.), Two Worlds of International Relations: Academics, Practitioners and the Trade in Ideas. London: Routledge, pp. 3-28.

Himmrich, JuliA. 2016. Bringing Academics Closer to Foreign Policy. Berlin: Dahrendorf Forum. Available from: http://www.dahrendorf-forum.eu/wp-content/uploads/2016/04/Bringing-AcademicsCloser-to-Foreign-Policy.pdf.

HM GOVERNMENT. 2014a. "DSTL's Work: Programmes and Facilities.” 1 July. Available from: https://www.gov.uk/government/collections/dstls-areas-of-work-programmes-and-project-portfolios.

- 2014b. The Allocation of Science and Research Funding 2015/16: Investing in World-Class Science and Research. London: Department for Business, Innovation and Skills. Available from: https://www.gov.uk/government/uploads/system/uploads/attachment_data/file/332767/bis-14-750science-research-funding-allocations-2015-2016-corrected.pdf.

—. 2015a. National Security Strategy and Strategic Defence and Security Review: A Secure and Prosperous United Kingdom. London: Cabinet Office. Available from: https://www.gov.uk/government/uploads/system/uploads/attachment_data/file/478933/52309_Cm_9 161_NSS_SD_Review_web_only.pdf.

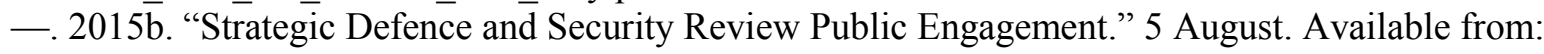
https://www.gov.uk/government/news/strategic-defence-and-security-review-public-engagement.

- 2016a. The Allocation of Science and Research Funding, 2016/17 to 2019/20. London: Department for Business, Innovation and Skills. Available from: https://www.gov.uk/government/uploads/system/uploads/attachment_data/file/505308/bis-16-160allocation-science-research-funding-2016-17-2019-20.pdf.

—. 2016b. Research at DfID. Available from: https://www.gov.uk/government/organisations/departmentfor-international-development/about/research.

—. 2016c. "Government announces new clause to be inserted into grant agreements." 6 February. Available from: https://www.gov.uk/government/news/government-announces-new-clause-to-beinserted-into-grant-agreements.

—. 2016d. Success as a Knowledge Economy: Teaching Excellence, Social Mobility and Student Choice. London: Department for Business, Innovation and Skills. Available from: https://www.gov.uk/government/uploads/system/uploads/attachment_data/file/523546/bis-16-265success-as-a-knowledge-economy-web.pdf.

HOFFMAN, ANDREW J. 2016. "Why academics are losing relevance in society - and what to do about it." The Conversation, 6 September. Available from: https://theconversation.com/why-academics-arelosing-relevance-in-society-and-how-to-stop-it-64579.

House OF COMMONS DEFENCE SELECT COMMITTEE. 2016. Shifting the Goalposts: Defence Expenditure and the 2\% Pledge. London: Parliament. Available from:

http://www.publications.parliament.uk/pa/cm201516/cmselect/cmdfence/494/494.pdf.

INMAN, PHILLIP. 2016. "Oxfam calls on Theresa May to tackle rising UK inequality." The Guardian, 13 September. Available from: https://www.theguardian.com/business/2016/sep/13/oxfam-calls-ontheresa-may-to-tackle-rising-uk-inequality.

JENKInS, SimON. 2016. "Renew Trident? It'd make more sense to put Dad's Army on the case." The Guardian, 13 January. Available from: https:/www.theguardian.com/commentisfree/2016/jan/13/renew-trident-dads-army-jeremy-corbynlabour.

JENTLESON, BRUCE W., AND Ely RATNER. 2011. "Bridging the Beltway-Ivory Tower Gap." International Studies Review 13(1): 6-11.

Jervis, RoBert. 1999. System Effects: Complexity in Political and Social Life. Princeton, NJ: Princeton University Press. 
JOHN, PETER. 2012. "How relevant is UK political science? A riposte to Matthew Flinders and Peter Riddell.” LSE Blogs, 17 April. Available from: http://blogs.lse.ac.uk/impactofsocialsciences/2012/04/17/political-science-relevant/.

KLEIN, EZRA. 2014. "The real reason nobody reads academics." BloombergView, 28 February. Available from: https://www.bloomberg.com/view/articles/2014-02-28/the-real-reason-nobody-readsacademics.

KLOTZ, AUDIE. 1995. "Norms Reconstituting Interests: Global Racial Equality and U.S. Sanctions Against South Africa." International Organization 49(3): 451-478.

KraUSS, LAWRENCE M. 2016. "Donald Trump's war on science." New Yorker, 13 December. Available from: http://www.newyorker.com/tech/elements/donald-trumps-war-on-science.

LEAHEY, ERIN, Christine M. BECKMAN, AND TARYN L. STANKO. 2017. "Prominent but Less Productive: The Impact of Interdisciplinarity on Scientists' Research." Administrative Science Quarterly 62(1): 105-139.

LLOYD, JAMES. 2016. "Should academics be expected to drive policy? Six reasons why it is unrealistic for research to drive policy change." LSE Blogs, 25 May. Available from: http://blogs.lse.ac.uk/impactofsocialsciences/2016/05/25/should-academics-be-expected-to-changepolicy-six-reasons-why-it-is-unrealistic/.

Macilwain, Colin. 2009. “The RAE: An Assessment Too Far?” Cell 139(4): 643-646.

MaliniaK, Daniel, Susan Peterson, AND Michael J. Tierney. 2012. TRIP Around the World: Teaching, Research, and Policy Views of International Relations Faculty in 20 Countries. Williamsburg: Institute for the Theory and Practice of International Relations, College of William and Mary. Available from:

https://www.wm.edu/offices/itpir/_documents/trip/trip_around_the_world_2011.pdf.

MALINIAK, DANiEl, SUSAN PETERSON, RYAN POWERS, AND MichĀEL J. TIERNĒEY. 2014. TRIP 2014 Faculty Survey. Williamsburg: Institute for the Theory and Practice of International Relations, College of William and Mary. Available from: https://trip.wm.edu/charts/\#/fullreport/36.

MANCE, HenRy. 2016. "Britain has had enough of experts, says Gove.” Financial Times, 3 June. Available from: https://www.ft.com/content/3be49734-29cb-11e6-83e4-abc22d5d108c.

Manville, Catriona, Susan Guthrie, Marie-Louise Henham, Bryn Garrod, Sonia Sousa, Anne KIRTLEY, SOPHIE CASTLE-ClARK, AND TOM LING. 2015. Assessing Impact Submissions for REF 2014: An Evaluation. Cambridge: RAND Europe. Available from: https://www.rand.org/content/dam/rand/pubs/research_reports/RR1000/RR1032/RAND_RR1032.pd f.

MARTIN, BEN R. 2011. "The Research Excellence Framework and the 'Impact Agenda': Are we Creating a Frankenstein Monster?" Research Evaluation 20(3): 247-254.

MATTHEWS, PETER. 2011. "Academic blogging and collaboration make demonstrating pathways to impact an easier matter." LSE Blogs, 3 November. Available from: http://blogs.lse.ac.uk/impactofsocialsciences/2011/11/03/blogging-pathways-to-impact/.

MCMahon, Michael F. 2007. Employability, Transferable Skills and Student Motivation. York: UK Higher Education Academy. Available from:

https://www.heacademy.ac.uk/system/files/employability_transferable_skills_and_student_motivatio n.docx.

MENDIZABAL, ENRIQUE. 2011. "The demands of proving 'impact' might tempt academics to work separately from think tanks, but a collaborative relationship between the two will yield the most productive results." LSE Blogs, 6 October. Available from: http://blogs.lse.ac.uk/impactofsocialsciences/2011/10/06/think-tanks-collaborative-relations/.

MERVIS, JEFFREY. 2014. "U.S. political scientists relieved that Coburn language is gone." Science, 23 January. Available from: http://www.sciencemag.org/news/2014/01/us-political-scientists-relievedcoburn-language-gone. 
MiNISTRY OF DEFENCE (UK). 2015. "Niteworks contract extended to 2018." Defence Contracts Online, 14 September. Available from: https://www.contracts.mod.uk/blog/niteworks-contract-extended-to2018/.

MOlas-GallaRT, JORDi. 2015. "Research Evaluation and the Assessment of Public Value." Arts and Humanities in Higher Education 14(1): 111-126.

MonBiot, GeORGE. 2009. “These men would've stopped Darwin.” The Guardian, 11 May. Available from: https://www.theguardian.com/commentisfree/2009/may/11/science-research-business.

MOONO, HERRYMAN. 2012. "Our research must eventually become irrelevant: this is how to prove we had an impact on policymaking." LSE Blogs, 13 February. Available from: http://blogs.lse.ac.uk/impactofsocialsciences/2012/02/13/research-impact-irrelevant/.

MORTON, SARAH. 2015. "Progressing Research Impact Assessment: A 'Contributions' Approach." Research Evaluation 24(4): 405-419.

NAU, HENRY R. 2008. "Scholarship and Policy-making: Who Speaks Truth to Whom?" in Christian Reus-Smit and Duncan Snidal (eds.), The Oxford Handbook of International Relations. Oxford: Oxford University Press, pp. 635-647.

NEWTON, PAUL. 2015. Thinking the Unthinkable: The MOD as an Indicative Case Study (University of Exeter Evidence to the House of Commons’ Defence Select Committee). London: Parliament, pp. 17. Available from:

http://data.parliament.uk/writtenevidence/committeeevidence.svc/evidencedocument/defencecommittee/an-sdsr-checklist-of-potential-threats/written/22550.pdf.

Ní Mhurchú, Aoileann, LAURA MCLeOd, StePhanie Collins, AND Gabriel SiLES-BrÜGge. 2016. "The Present and Future of the Research Excellence Framework Impact Agenda in the UK Academy: A Reflection from Politics and International Studies.” Political Studies Review 15(1): 6072.

Nichols, ToM. 2017. The Death of Expertise: The Campaign Against Established Knowledge and Why It Matters. Oxford: Oxford University Press.

Nutley, SANDRA M., IsABel Walter, AND Huw T. O. DaVies. 2007. Using Evidence: How Research Can Inform Public Services. Bristol: Policy Press.

NyE, JoSEPH S. 1990. "Soft Power." Foreign Policy 80: 153-171.

-. 2008. "International Relations: The Relevance of Theory to Practice" in Christian Reus-Smit and Duncan Snidal (eds.), The Oxford Handbook of International Relations. Oxford: Oxford University Press, pp. 648-661.

O'BRIEN, CHRIS. 2015. "Latest news and views on the next REF." The Bulletin, 4 August. Available from: http:/www.bulletin.co.uk/31443/latest-news-views-next-ref/.

OLIVER, KATHRYN. 2014. "What's the Impact of the Research Impact Agenda?" UCL STEaPP, 27 May. Available from: https://www.ucl.ac.uk/steapp/steapp-news-publication/2013-14/impact-agendaoliver.

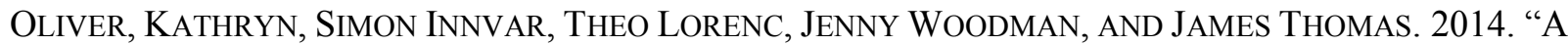
Systematic Review of Barriers to and Facilitators of the Use of Evidence by Policymakers." BMC Health Services Research 14(2): 1-12.

Olmos-Peñuela, Julia, Paul BenNeworth, and Elena Castro-Martinez. 2015. “Are Sciences Essential and Humanities Elective? Disentangling Competing Claims for Humanities' Research Public Value." Arts and Humanities in Higher Education 14(1): 61-78.

PHIPPS, ALISON. 2014. "The dark side of the Impact Agenda." Times Higher Education Supplement, 4 December. Available from: https://www.timeshighereducation.com/comment/opinion/the-dark-sideof-the-impact-agenda/2017299.article.

PHILLIPS, RICHARD. 2010. "The Impact Agenda and Geographies of Curiosity." Transactions of the Institute of British Geographers 35(4): 447-452.

PORTER, PATRICK. 2010. "Why Britain Doesn't Do Grand Strategy.” RUSI Journal 155(4): 6-12. 
-. 2016. "A Proud Day for Parliament: The Wisdom of Not Bombing Assad." WarOnTheRocks.com, 30 March. Available from: https://warontherocks.com/2016/03/a-proud-day-for-parliament-the-wisdomof-not-bombing-assad/.

Preble, ChristoPHER. 2017. "Bridging the Gap: Managing Expectations, Improving Communication." Journal of Strategic Studies 40(1-2): 275-282.

Provost, Claire. 2012. "DfID's spending on consultants to come under increased scrutiny." The Guardian, 17 September. Available from: https:/www.theguardian.com/globaldevelopment/2012/sep/17/dfid-spending-consultants-scrutiny.

RAE. 2008. Changes since the RAE 2001. Available from: http://www.rae.ac.uk/aboutus/changes.asp.

RATCLIFFE, REBECCA. 2014. "REF 2014: why is it such a big deal?" The Guardian, 17 December. Available from: https://www.theguardian.com/higher-education-network/2014/dec/17/ref-2014-whyis-it-such-a-big-deal.

RAYNER, GORDON. 2011. "MoD pays $£ 150,000$ to pulp Afghanistan book after bureaucratic blunder." The Telegraph, 3 March. Available from: http:/www.telegraph.co.uk/news/uknews/defence/8360276/MoD-pays-150000-to-pulp-Afghanistanbook-after-bureaucratic-blunder.html.

RCUK. 2012a. Pathways to Impact. Available from: http://www.rcuk.ac.uk/innovation/impacts/.

- 2012b. RCUK Review of Pathways to Impact: Summary, Swindon: Research Councils UK. Available from: http://www.rcuk.ac.uk/documents/documents/ptoiexecsummary-pdf/.

- 2014a. Impact Acceleration Accounts - a common Research Councils approach. Available from: http://www.rcuk.ac.uk/innovation/impact-accelerator-accounts/.

—. 2014b. Open Access. Available at: http://www.rcuk.ac.uk/research/openaccess/.

REF. 2012a. Assessment criteria and level definitions. Available at: http://www.ref.ac.uk/panels/assessmentcriteriaandleveldefinitions/.

—. 2012b. REF2014 Impact Case Studies. Available at: http://impact.ref.ac.uk/CaseStudies/FAQ.aspx.

—. 2012c. Units of Assessment: REF 2014. Available at: http://www.ref.ac.uk/panels/unitsofassessment/.

Reus-Smit, Christian. 2012. "International Relations, Irrelevant? Don't Blame Theory." Millennium: Journal of International Studies 40(3): 525-540.

Rogers, Amanda, Christopher Bear, Mia Hunt, Sarah Mills, and Rebecca Sandover. 2014. "Intervention: The Impact Agenda and Human Geography in UK Higher Education." ACME 13(1): $1-9$.

ROYAL SOCIETY. 2016. Pairing Scheme. Available from: https://royalsociety.org/grants-schemesawards/pairing-scheme/.

RUTTER, JILL. 2011. "It's time for academics to help shape not just individual policies, but a new system of policy-making that allows for a more effective feedback process and implementation of policy." LSE Blogs, 1 July. Available from:

http://blogs.lse.ac.uk/impactofsocialsciences/2011/07/01/it\%E2\%80\%99s-time-for-academics-tohelp-shape-not-just-individual-policies-but-a-new-system-of-policy-making-that-allows-for-a-moreeffective-feedback-process-and-implementation-of-policy/.

SAYER, DEREK. 2014. "Five reasons why the REF is not fit for purpose." The Guardian, 15 December. Available from: https://www.theguardian.com/higher-education-network/2014/dec/15/researchexcellence-framework-five-reasons-not-fit-for-purpose.

SEAGER, ASHLEY, JULIA KOLLEWE, AND KATHRYN HOPKINS. 2009. "UK economy in its longest recession on record." The Guardian, 23 October. Available from: https://www.theguardian.com/business/2009/oct/23/uk-economy-lonest-recession-record.

SEBBA, JUDY. 2011. "Getting research into policy: the role of think tanks and other mediators." LSE Blogs, 7 March. Available from: http://blogs.lse.ac.uk/impactofsocialsciences/2011/03/07/gettingresearch-into-policy-the-role-of-think-tanks-and-other-mediators/. 
SMITH, SimON, VICKY WARD, AND AlLAN HOUSE. 2011. "'Impact' in the Proposals for the UK's Research Excellence Framework: Shifting the Boundaries of Academic Autonomy." Research Policy 40(10): 1369-1379.

STERN, NICHOLAS. 2016. Building on Success and Learning from Experience: An Independent Review of the Research Excellence Framework. London: Department of Business, Energy and Industrial Strategy. Available from:

https://www.gov.uk/government/uploads/system/uploads/attachment_data/file/541338/ind-16-9-refstern-review.pdf.

STOKER, GERRY, AND MARK EvANS. 2016. "Introduction” in Gerry Stoker and Mark Evans (eds.), Evidence-based Policy Making in the Social Sciences: Methods that Matter. Bristol: Policy Press, pp. 1-12.

Strachan, Hew. 2009. “The Strategic Gap in British Defence Policy.” Survival 51(4), pp. 49-70.

- 2013. "A War Examined: Allies and Ethics - British National Strategy: Who Does It?" Parameters 43(2): 43-52.

SAMUEL, GABRIELlE N., AND GEMMA E. DERRICK. 2015. "Societal Impact Evaluation: Exploring Evaluator Perceptions of the Characterization of Impact under the REF2014." Research Evaluation 24(3): 229-241.

Talbot, Colin, and Carole Talbot. 2014. Sir Humphrey and the Professors: What does Whitehall want from Academics? Manchester: University of Manchester. Available from:

http://hummedia.manchester.ac.uk/faculty/policy/1008_Policy@Manchester_Senior_Civil_Servants Survey_v4(1).pdf.

TANNENWALD, NinA. 1999. "The Nuclear Taboo: The United States and the Normative Basis of Nuclear Non-Use.” International Organization 53(3): 433-468.

THE CONVERSATION. 2016. Pitch an article idea. Available from: https://theconversation.com/uk/pitches.

THE GUARDIAN. 2010. "Opinion: Pitch guidelines.” 4 March. Available from: https://www.theguardian.com/commentisfree/2010/mar/04/you-tell-us.

THE TELEGRAPH. 2015. "Aid budget spending on consultants 'doubles to $£ 1.4 \mathrm{bn}$ '." 17 April. Available from: http://www.telegraph.co.uk/news/politics/11543980/Aid-budget-spending-on-consultantsdoubles-to-1.4bn.html.

UNIVERSITIES UK. 2015. The Funding Environment for Universities 2015: The Economic Role of UK Universities. London: Universities UK. Available from: http://www.universitiesuk.ac.uk/policy-andanalysis/reports/Documents/2015/the-economic-role-of-uk-universities.pdf.

Upton, STeVie, Paul Vallance, And John Goddard. 2014. "From Outcomes to Process: Evidence for a New Approach to Research Impact Assessment." Research Evaluation 23(4): 352-365.

VARIAN, HAL R. 2003. Intermediate Microeconomics: A Modern Approach (6 ${ }^{\text {th }}$ ed.). New York: Norton.

VInCENT, ANDREW. 2015. "The Ideological Context of Impact." Political Studies Review 13(4): 474-484.

WALT, STEPHEN M. 2005. "The Relationship between Theory and Policy in International Relations." Annual Review of Political Science 8: 23-48.

—. 2012. "Theory and Policy in International Relations: Some Personal Reflections." Yale Journal of International Affairs 7(2): 33-43.

Weiss, CAROL H. 1979. "The Many Meanings of Research Utilization." Public Administration Review 39(5): 426-431.

WendT, ALEXANDER. 1992. "Anarchy Is What States Make of It: The Social Construction of Power Politics." International Organization 46(2): 391-425.

WIERS, JOCHEM. 2017. “Building a Bridge or Nurturing a Gap?” Journal of Strategic Studies 40(1-2): 283-286.

WILLIAMSON, ANDY. 2011. "The think-tank model has passed its use by date. We need an alternative model for quality research to impact on evidence-based policy-making." LSE Blogs, 17 October. Available from: http://blogs.lse.ac.uk/impactofsocialsciences/2011/10/17/think-tank-passed-use-bydate/. 
WILSDON, JAMES. 2016. “The road to REF 2021: why I welcome Lord Stern's blueprint for research assessment." The Guardian, 29 July. Available from: https://www.theguardian.com/science/politicalscience/2016/jul/29/why-i-welcome-lord-sterns-blueprint-for-research-assessment-ref-2021-sternreview.

WILSON, T. D. 1987. “The Impact of Research.” International Journal of Information Management 7(2): 95-96.

WINNETT, ROBERT. 2015. "George Osborne: defence spending rise means UK can 'deal with whatever the world throws at us'." The Telegraph, 28 July. Available from:

http://www.telegraph.co.uk/news/uknews/defence/11769239/George-Osborne-Defence-spendingrise-means-UK-can-deal-with-whatever-the-world-throws-at-us.html.

WoOD, MATT. 2012. "An insider view on the relevance of political scientists to government." LSE Blogs, 30 May. Available from: http://blogs.lse.ac.uk/impactofsocialsciences/2012/05/30/insider-viewrelevance-political-scientists-goverment/.

YOUNG, LiAM. 2016. "Jeremy Corbyn's got it right on Trident - Labour MPs should follow his lead." New Statesman, 18 July. Available from:

http://www.newstatesman.com/politics/staggers/2016/07/jeremy-corbyns-got-it-right-trident-labourmps-should-follow-his-lead.

ZAMBERNARDI, LORENZO. 2016. "Politics is too important to be left to political scientists: A Critique of the Theory-Policy Nexus in International Relations." European Journal of International Relations 22(1): 3-23. 